\title{
A functional flows approach to selecting ecologically relevant flow metrics for environmental flow applications
}

Short running title: Functional flow metrics for environmental flow applications

Sarah M. Yarnell ${ }^{\mathrm{a}}$, Eric D. Stein ${ }^{\mathrm{b}}$, J. Angus Webb ${ }^{\mathrm{c}}$, Theodore Grantham ${ }^{\mathrm{d}}$, Rob A. Lusardi ${ }^{\mathrm{a}}$ e , Julie Zimmerman ${ }^{\mathrm{f}}$, Ryan A. Peek ${ }^{\mathrm{a}}$, Belize A. Lane ${ }^{\mathrm{g}}$, Jeanette Howard ${ }^{\mathrm{f}}$, and Samuel Sandoval-Solis ${ }^{\mathrm{h}}$

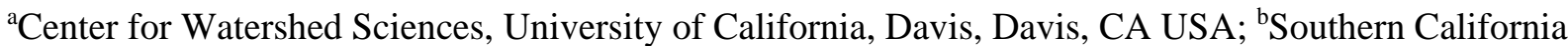
Coastal Water Research Project, Costa Mesa, CA USA; 'Water, Environment and Agriculture Program, The University of Melbourne, Melbourne AUS; ${ }^{\mathrm{d}}$ Department of Environmental Science, Policy and Management, University of California, Berkeley, Berkeley, CA USA; ${ }^{\mathrm{e} C a l i f o r n i a ~ T r o u t, ~ S a n ~ F r a n c i s c o, ~}$ CA USA; ${ }^{\mathrm{f}}$ The Nature Conservancy, Sacramento, CA USA; ${ }^{\mathrm{g}}$ Department of Civil and Environmental Engineering, Utah State University, Logan, UT USA; 'hand, Air, Water Resources Department, University of California, Davis, Davis, CA USA

Corresponding Author: Sarah Yarnell, smyarnell@ucdavis.edu.

\section{Acknowledgements}

The authors extend gratitude to Larry Brown at the US Geological Survey for his insightful comments and discussion regarding the development of this work. We also thank Mike Dunbar and an anonymous reviewer for their comments and suggestions on the manuscript. Funding for this work was provided by the California State Water Resources Control Board and The Nature Conservancy.

\begin{abstract}
The science and practice of environmental flows has advanced significantly over the last several decades. Most environmental flow approaches require quantifying the relationships between hydrologic change and biologic response, but this can be challenging to determine and implement due to high data This is the author manuscript accepted for publication and has undergone full peer review but has not been through the copyediting, typesetting, pagination and proofreading process, which may lead to differences between this version and the Version of Record. Please cite this article as doi: $10.1002 /$ rra.3575
\end{abstract}

This article is protected by copyright. All rights reserved. 
requirements, limited transferability, and the abundance of hydrologic metrics available for evaluation. We suggest that a functional flows approach, focusing on elements of the natural flow regime known to sustain important ecosystem processes, offers a pathway for linking understanding of ecosystem processes with discrete, quantifiable measures of the flow regime for a broad range of native taxa and assemblages. Functional flow components can be identified as distinct aspects of the annual hydrograph that support key biophysical processes, such as wet-season flood flows or spring recession flows, and then quantified by flow metrics, such as $5 \%$ exceedance flow or daily percent decrease in flow, respectively. By selecting a discrete set of flow metrics that measure key functional flow components, the spatial and temporal complexity of flow regimes can be managed in a holistic manner supportive of multiple ecological processes and native aquatic species requirements. We provide an overview of the functional flows approach to selecting a defined set of flow metrics and illustrate its application in two seasonally variable stream systems. We further discuss how a functional flows approach can be utilized as a conceptual model both within and outside of existing environmental flow frameworks to guide consideration of ecological processes when designing prescribed flow regimes.

Keywords: environmental flows; flow metrics; functional flows; flow-ecology; holistic method 


\section{Introduction}

The development and implementation of environmental flows (hereafter termed e-flows) is widely recognized as critical to the restoration and conservation of freshwater ecosystems and species globally (Poff, Tharme, \& Arthington, 2017). Scientific advances over the past several decades reflect this understanding with the development of over 200 e-flow assessment methodologies (Tharme, 2003) and the creation of large-scale political governance structures to support and implement water management actions that explicitly account for ecosystem services and sustainability (e.g., European Water Framework Directive; Murray-Darling Basin Plan, Australia). More recently, e-flow science is converging around holistic methods that consider the complexity of flow variation across space and time by evaluating broad sets of hydrologic metrics in relation to biological indicators (e.g., ELOHA (Poff et al., 2010), DRIFT (King, Brown, \& Sabet, 2003)). While agreed upon as conceptually sound, these methods can be challenging to implement due to the abundance of hydrologic metrics available for evaluation (Eng, Grantham, Carlisle, \& Wolock, 2017; Richter, Baumgartner, Powell, \& Braun, 1996), many of which lack biological relevance (Carlisle, Grantham, Eng, \& Wolock, 2017) or are redundant (Olden \& Poff, 2003), and a lack of consistent relationships between flow and ecologic response (Webb et al., 2013). For example, ELOHA recommends selecting flow metrics that reflect empirical ecological-flow relationships developed from coupled eco-hydrologic data across a gradient of alteration (Poff et al., 2010). However, such data are seldom available at sufficient density to support the intended analysis, can be expensive to obtain, and often only represent a snapshot in time and space. Furthermore, biotic assemblages for which data are available may not broadly represent the ecology of the entire stream ecosystem, or relationships developed with available data may be inconclusive or have limited transferability (Poff \& Zimmerman, 2010). As a result, scientists and practitioners continue to struggle to find a discrete set of flow metrics that adequately quantify aspects of a flow regime that must be protected in order to sustain river ecosystem structure and function.

We propose a functional flows approach to guide the selection of flow metrics that is grounded in our understanding of riverine ecosystem processes. The approach relies on the identification of functional flow components, which are discrete aspects of the flow regime that have documented relationships with ecological, geomorphic or biogeochemical processes in riverine systems (Yarnell et al., 2015). For 
example, over-bank (flood) flows are a well-recognized functional flow component that supports a broad suite of physical and ecological processes, including the maintenance of habitat heterogeneity in space and time (Ward, 1998), providing cues for fish migration and reproduction (Jeffres, Opperman, \& Moyle, 2008), and controlling patterns of riparian succession (Ward \& Stanford, 1995). The functional flows approach rests on the assumption that managing for these key flow components will preserve the necessary hydrologic signals upon which biophysical processes and native biological communities depend. Once defined, flow components are described by functional flow characteristics including magnitude, timing, duration, frequency, or rate of change (Poff et al., 1997), which can then be expressed by flow metrics (e.g., 5\% exceedance flow) that together quantify the functional components of the flow regime (Figure 1). Collectively, the discrete set of functional flow metrics provides the means to focus eflow assessment and implementation on quantitative attributes of the flow regime that are most important for the maintenance of river ecosystem structure and function.

The proposed functional flows approach complements holistic e-flow assessment methods, such as ELOHA or DRIFT, by guiding the selection of metrics to ensure all functional flow components, and their associated physical and biological processes, are considered in the development and implementation of e-flow recommendations. The approach can also be applied independently of existing e-flow frameworks, and may be particularly well-suited to data-poor regions, where there are insufficient data to develop empirical ecological-flow relationships to set e-flow targets. In such contexts, generally recognized or hypothesized relationships between functional flow components and ecosystem health can be used to guide the selection of metrics to incorporate into e-flow programs.

Here, we provide an overview of the functional flows approach to select a set of flow metrics that quantify key ecological components of the flow regime, and we illustrate its application in two seasonally variable climate regions. We then discuss how a functional flows approach can be utilized as a conceptual model both within and outside of existing e-flow frameworks to promote deeper consideration of ecological processes when assessing and prescribing e-flows.

\section{Quantifying Functional Flow Components}


Initial identification of the functional flow components needed to support an aquatic community begins with a literature review of documented flow-ecology relationships, coupled with local knowledge and expertise on regional flow patterns and biota. For example, Yarnell et al. (2015) reviewed the scientific literature and identified four key functional flow components required to support a variety of ecological, geomorphic and biogeochemical processes for Mediterranean-montane streams. These included peak magnitude flows, spring recession flows, dry-season low flows, and wet-season initiation flows. Similar flow components have been identified in other seasonal river systems, such as the Waterton River in Canada (Foster, Mahoney, \& Rood, 2018), the Spol River in Switzerland (Robinson, Siebers, \& Ortlepp, 2018), and both inland and coastal rivers in Australia (Koster, Dawson, O'Mahony, Moloney, \& Crook, 2014; Webb, Koster, Stuart, Reich, \& Stewardson, 2018). These functional flow components are likely relevant for other seasonal climates, and can provide a starting point for assessment in locations with limited data availability.

Each functional flow component can be described by a suite of flow characteristics, such as magnitude, timing, duration, frequency, and rate of change. For example, the spring recession flow can be defined by characteristics including magnitude, timing, duration, and rate of change of streamflow, while peak magnitude flows can be represented by magnitude, timing, frequency, and duration characteristics (Figure 2). These flow characteristics, in turn, can be quantified by flow metrics (Figure 1). The selection of specific flow metrics that best represent each flow characteristic can be informed by their established ecological relevance (e.g., relationship to life history needs of species and/or empirical relationship between a metric and an indicator of ecological impairment), predictability in numeric modelling (Eng et al., 2017), sensitivity to flow alteration, and/or feasibility of implementation in management operations. In this manner, the selection of flow metrics is flexible but guided by understanding of how stream ecosystem processes are dependent on specific components of the flow regime.

Use of conceptual models linking functional flow components with desired ecological outcomes also allows for the development and testing of hypotheses regarding flow-ecology relationships, including assessments of efficacy (Davies et al., 2014). Exploring the empirical relationships between a functional flow metric and a biotic response generates evidence for inclusion and/or refinement of the associated flow component in conceptual models. For example, studies have shown dry-season low flows with 
minimal daily stage fluctuations (low rate of change) support more diverse benthic macroinvertebrate communities; Steel, Peek, Lusardi, and Yarnell (2017) quantified the rate of change in baseflow with the coefficient of variation of daily flow, while Mazor et al. (2018) quantified the rate of change in baseflow with the Richards-Baker Flashiness Index. Despite different flow metrics, both studies found positive relationships with low flow stability and benthic community diversity suggesting a key flow-ecology relationship to be retained within conceptual models for this system.

\section{Functional Flow Metrics for Seasonal Flow Regimes}

The selection of flow metrics corresponding to the flow characteristics of functional flow components should be informed by the following criteria (modified after Poff et al., 2010):

- Easily quantified and directly describes a flow characteristic of a functional flow component (i.e., magnitude, duration, frequency, timing, rate of change)

- Relates responses in aquatic community to hydrology

- Relates to key life history needs of native aquatic species or communities

- Can be used to establish thresholds useful for management purposes

The scientific literature on flow metrics and quantification of flow regimes is broad, and a majority of approaches seek to link hydrology to ecology by determining which metrics have a statistically significant relationship to ecological endpoints (e.g. Olden \& Poff, 2003). For example, studies have tested which metrics are the best predictors of altered flows (e.g. Kennard et al., 2010) or most associated with impaired biology (e.g. Poff \& Zimmerman, 2010), and which flow metrics best describe the life history needs of a particular species (e.g. Miller et al., 2018) or biotic community (e.g. McMullen \& Lytle, 2012). While some have suggested the domain of potential flow metrics can be reduced based on their redundancy (Olden \& Poff, 2003), others have cautioned against rejecting metrics prior to evaluating their relationships to ecological endpoints to avoid overlooking potentially important hydro-ecological associations (Monk, Wood, Hannah, \& Wilson, 2007). Rather than using statistical methods to initially select flow metrics, a functional flows approach can guide the selection of metrics based on their representation of ecosystem processes and general importance to aquatic and riparian communities. To 
illustrate this approach, we identified flow metrics that quantify flow characteristics of key functional flow components for California’s Mediterranean streams (Yarnell et al., 2015) and for the Goulburn River in Australia’s Murray-Darling Basin (Vietz, Lintern, Webb, \& Straccione, 2018; Webb et al., 2019).

Based on the body of literature for Mediterranean-climate rivers, we identified a series of flow metrics that correspond to functional flow components and are important for particular aquatic and riparian communities of interest for California (Table 1; Appendix A). For example, riparian plants rely on the frequency of wet-season peak flows and a predictable spring recession with low rates of change, while native fish are responsive to the flow magnitude of each functional flow component (Appendix A). Since wet-season baseflows were also found to be important for stream network connectivity and fish passage in northern California streams (Grantham, 2013), an additional functional flow component was added to the original conceptual model (Table 1). Where data gaps exist (e.g., response of riparian plants to dryseason baseflow), the conceptual model can be used to develop hypotheses regarding flow-ecology relationships that can be tested in future studies.

For the Goulburn River in Australia, similar functional flow components have been shown to support ecological processes and species of interest through research and monitoring of environmental flows delivered under the Australian Government's Murray-Darling Basin Plan, specifically through the LongTerm Intervention Monitoring Project (LTIMP) (Gawne et al., early view) (Table 2). High flow pulses in fall and spring have proved important for native fish breeding and migration responses and the condition of riparian vegetation. Wet season peak flows that inundate the floodplain have been shown to be important for secondary production of macroinvertebrates in the river channel. The duration of wetseason peak flows, and the corresponding inundation of river banks, is strongly correlated with erosion and deposition processes with differing effects depending on the timing of the individual flood event (Vietz et al., 2018; Webb et al., 2019). The broad applicability of these and other functional flow components is being tested across other rivers of the Murray-Darling Basin that are part of the LTIMP.

In areas where general knowledge of the natural flow regime is available but detailed data on species-flow linkages are missing or incomplete, functional flow metrics quantifying the natural ranges of flow 
characteristics for each functional flow component can serve as the basis for developing interim flow requirements until site-specific data are available.

\section{Incorporating Functional Flows in Environmental Flow Frameworks}

The proposed approach for selecting functional flow metrics can be incorporated in a variety of e-flow frameworks. At a broad regional scale, the suite of functional flow metrics quantifying key flow characteristics of functional flow components can provide initial flow targets hypothesized to be broadly protective of aquatic species and communities. For example, in California, the California Environmental Flows Framework (ceff.ucdavis.edu) is a hydrologically-based method founded on the functional flows approach that provides reference-based ecological flow criteria for all streams in the state of California. The framework uses reference hydrologic expectations to predict a set of functional flow metrics (Table 1) that fully quantify functional flow components for each stream in the state. This method provides a consistent, ecologically relevant and spatially-explicit foundation for subsequent e-flow analysis. Recently, stakeholders in the Goulburn River watershed in Australia have committed to a new e-flows assessment study that will specifically include functional flows in network-based conditional probability models (Horne et al., 2018) that explicitly link multiple flow components to ecological response through direct and indirect relationships.

The functional flows approach outlined here complements existing holistic frameworks such as ELOHA (Poff et al., 2010), which typically require either single species or community-based flow-ecology relationships to establish environmental flow targets. Application of the ELOHA framework requires that these relationships be quantified for different species to represent combined flow needs across the flow regime. In addition, relationships need to be defined for different stream types, making application across regions cumbersome, particularly where data are limited. A functional flows approach effectively provides a foundation for establishing flow-ecology hypotheses and determining flow-ecology relationships (step 4 of ELOHA) through development of a conceptual model of flow components broadly supportive of native aquatic communities and subsequent selection of flow metrics that represent those relationships.

\section{Summary}


Here, we offer an approach to address the persistent challenge of selecting ecologically relevant flow metrics when developing environmental flow recommendations. We suggest that identifying and quantifying functional flow components provides a way to link ecological understanding of stream processes with discrete quantifiable measures of flow. From an ecological perspective, we ask what flow components (aspects of the annual hydrograph) are most important to sustain ecological processes and functions in a stream system, and then seek to quantify those components with ecologically-relevant flow metrics. In this manner, we seek to emphasize ecology when quantifying environmental flow regimes by developing a priori hypotheses of functional flow components and flow characteristics that are expected to broadly support river-dependent species and communities (Shenton, Bond, Yen, \& Mac Nally, 2012). This results in a holistic, multi-dimensional approach for developing ecologically-relevant flow regimes that accounts for flow complexity in space and time through identification of a finite set of representative flow metrics. Furthermore, organization of flow metrics by functional flow component allows us to explore how specific quantifiable metrics perform in describing ecologic response to flows without losing sight of the broader context in which flow regimes sustain stream ecosystems. 


\section{Data Availability Statement}

Data sharing is not applicable to this article as no new data were created or analyzed in this study.

\section{References}

Carlisle, D. M., Grantham, T. E., Eng, K., \& Wolock, D. M. (2017). Biological relevance of streamflow metrics: regional and national perspectives. Freshwater Science, 36(4), 927940. doi:10.1086/694913

Davies, P. M., Naiman, R. J., Warfe, D. M., Pettit, N. E., Arthington, A. H., \& Bunn, S. E. (2014). Flow-ecology relationships: closing the loop on effective environmental flows. Marine and Freshwater Research, 65(2), 133-141.

Eng, K., Grantham, T. E., Carlisle, D. M., \& Wolock, D. M. (2017). Predictability and selection of hydrologic metrics in riverine ecohydrology. Freshwater Science, 36(4), 915-926. doi:10.1086/694912

Foster, S. G., Mahoney, J. M., \& Rood, S. B. (2018). Functional flows: an environmental flow regime benefits riparian cottonwoods along the Waterton River, Alberta. Restoration Ecology, 26(5), 921-932. doi:10.1111/rec.12654

Gawne, B., Hale, J., Stewardson, M. J., Webb, J. A., Ryder, D. S., Brooks, S. S., . . Stoffels, R. J. (early view). Monitoring of environmental flow outcomes in a large river basin: The Commonwealth Environmental Water Holder's long-term intervention in the Murray Darling Basin, Australia. River Research and Applications. doi:10.1002/rra.3504

Grantham, T. E. (2013). Use of hydraulic modelling to assess passage flow connectivity for salmon in streams. River Research and Applications, 29(2), 250-267.

Horne, A. C., Szemis, J. M., Webb, J. A., Kaur, S., Stewardson, M. J., Bond, N., \& Nathan, R. (2018). Informing environmental water management decisions: Using conditional probability networks to address the information needs of planning and implementation cycles. Environmental Management, 61, 347-357.

Jeffres, C. A., Opperman, J. J., \& Moyle, P. B. (2008). Ephemeral floodplain habitats provide best growth conditions for juvenile Chinook salmon in a California river. Environmental Biology of Fishes, 83(4), 449-458. doi:10.1007/s10641-008-9367-1 
Kennard, M. J., Pusey, B. J., Olden, J. D., Mackay, S. J., Stein, J. L., \& Marsh, N. (2010). Classification of natural flow regimes in Australia to support environmental flow management. Freshwater Biology, 55(1), 171-193.

King, J., Brown, C., \& Sabet, H. (2003). A scenario-based holistic approach to environmental flow assessments for rivers. River Research and Applications, 19(5-6), 619-639. doi:10.1002/rra.709

Koster, W. M., Dawson, D. R., O'Mahony, D. J., Moloney, P. D., \& Crook, D. A. (2014). Timing, frequency and environmental conditions associated with mainstem-tributary movement by a lowland river fish, Golden Perch (Macquaria ambigua). Plos One, 9, 12.

Mazor, R. D., May, J., Sengupta, A., McCune, K. S., Bledsoe, B., \& Stein, E. D. (2018). Tools for managing hydrologic alteration on a regional scale: Setting targets to protect stream health. Freshwater Biology. doi:10.1111/fwb.13062

McMullen, L. E., \& Lytle, D. A. (2012). Quantifying invertebrate resistance to floods: a globalscale meta-analysis. Ecological Applications, 22, 2164-2175.

Miller, K. A., Casas-Mulet, R., Webb, J. A., de Little, S. C., Stewardson, M. J., \& Koster, W. M. (2018). Deficiencies in our understanding of the hydro-ecology of several native Australian fish: a rapid evidence synthesis. Marine and Freshwater Research, 69, 12081221.

Monk, W. A., Wood, P. J., Hannah, D. M., \& Wilson, D. A. (2007). Selection of river flow indices for the assessment of hydroecological change. River Research and Applications, 23(1), 113-122. doi:10.1002/rra.964

Olden, J. D., \& Poff, N. L. (2003). Redundancy and the choice of hydrologic indices for characterizing streamflow regimes. River Research and Applications, 19(2), 101-121. doi:10.1002/rra.700

Poff, N. L., Allan, J. D., Bain, M. B., Karr, J. R., Prestegaard, K. L., Richter, B. D., . . Stromberg, J. C. (1997). The natural flow regime. Bioscience, 47(11), 769-784.

Poff, N. L., Richter, B. D., Arthington, A. H., Bunn, S. E., Naiman, R. J., Kendy, E., ... Warner, A. (2010). The ecological limits of hydrologic alteration (ELOHA): a new framework for developing regional environmental flow standards. Freshwater Biology, 55(1), 147-170. doi:10.1111/j.1365-2427.2009.02204.x 
Poff, N. L., Tharme, R. E., \& Arthington, A. H. (2017). EVOLUTION OF ENVIRONMENTAL FLOWS ASSESSMENT SCIENCE, PRINCIPLES, AND METHODOLOGIES.

Poff, N. L., \& Zimmerman, J. K. (2010). Ecological responses to altered flow regimes: a literature review to inform the science and management of environmental flows. Freshwater Biology, 55(1), 194-205.

Richter, B. D., Baumgartner, J. V., Powell, J., \& Braun, D. P. (1996). A method for assessing hydrologic alteration within ecosystems. Conservation Biology, 10(4), 1163-1174.

Robinson, C. T., Siebers, A. R., \& Ortlepp, J. (2018). Long-term ecological responses of the River Spol to experimental floods. Freshwater Science, 37(3), 433-447. doi:10.1086/699481

Shenton, W., Bond, N. R., Yen, J. D. L., \& Mac Nally, R. (2012). Putting the "Ecology" into Environmental Flows: Ecological Dynamics and Demographic Modelling. Environmental Management, 50(1), 1-10. doi:10.1007/s00267-012-9864-z

Steel, A. E., Peek, R. A., Lusardi, R. A., \& Yarnell, S. M. (2017). Associating metrics of hydrologic variability with benthic macroinvertebrate communities in regulated and unregulated snowmelt-dominated rivers. Freshwater Biology. doi:10.1111/fwb.12994

Tharme, R. E. (2003). A global perspective on environmental flow assessment: emerging trends in the development and application of environmental flow methodologies for rivers. River Research and Applications, 19(5-6), 397-441. doi:10.1002/rra.736

Vietz, G. J., Lintern, A., Webb, J. A., \& Straccione, D. (2018). River bank erosion and the influence of environmental flow management. Environmental Management, 61, 454-468.

Ward, J. V. (1998). Riverine landscapes: Biodiversity patterns, disturbance regimes, and aquatic conservation. Biological Conservation, 83(3), 269-278.

Ward, J. V., \& Stanford, J. A. (1995). Ecological Connectivity in Alluvial River Ecosystems and Its Disruption By Flow Regulation. Regulated Rivers-Research \& Management, 11(1), 105-119.

Webb, J. A., Guo, D., King, E., Treadwell, S., Baker, B., Casanelia, S., . . Vietz, G. (2019). Commonwealth Environmental Water Office Long Term Intervention Monitoring Project Goulburn River Selected Area Summary Report 2017-18. Retrieved from Melbourne, Australia.

This article is protected by copyright. All rights reserved. 
Webb, J. A., Koster, W. M., Stuart, I. G., Reich, P., \& Stewardson, M. J. (2018). Make the most of the data you've got: Bayesian models and a surrogate species approach to assessing benefits of upstream migration flows for the endangered Australian grayling. Environmental Management, 61, 398-407.

Webb, J. A., Miller, K. A., King, E. L., de Little, S. C., Stewardson, M. J., Zimmerman, J. K. H., \& Poff, N. L. (2013). Squeezing the most out of existing literature: a systematic reanalysis of published evidence on ecological responses to altered flows. Freshwater Biology, 58(12), 2439-2451. doi:10.1111/fwb.12234

Yarnell, S. M., Petts, G. E., Schmidt, J. C., Whipple, A. A., Beller, E. E., Dahm, C. N., ... Viers, J. H. (2015). Functional Flows in Modified Riverscapes: Hydrographs, Habitats and Opportunities. Bioscience, 65(10), 963-972. doi:10.1093/biosci/biv102 


\section{Tables}

Table 1. Summary of functional flow metrics that have been shown in the literature to link to aquatic species or communities of interest applicable to California organized by functional flow component and associated flow characteristics. ' $\mathrm{X}$ ' indicates one or more studies linking the aquatic community (benthic macroinvertebrates (BMI), fish, or riparian) with the flow metric. Citations are provided in Appendix A.

\begin{tabular}{|c|c|c|c|c|c|}
\hline Flow Component & $\begin{array}{c}\text { Flow } \\
\text { Characteristic }\end{array}$ & Flow Metric & BMI & Fish & Riparian \\
\hline \multirow{3}{*}{ Fall pulse flow } & Magnitude & peak of flushing flow & & $\mathrm{X}$ & \\
\hline & Timing & start date & $\mathrm{X}$ & $\mathrm{X}$ & \\
\hline & Duration & \# days (start - end) & & & \\
\hline \multirow{3}{*}{$\begin{array}{l}\text { Wet-season base } \\
\text { flow }\end{array}$} & Magnitude & $\begin{array}{l}\text { 10th, 90th percentile of daily } \\
\text { flow within wet-season }\end{array}$ & & $\mathrm{X}$ & \\
\hline & Timing & start date & & & \\
\hline & Duration & \# days (start - end) & & & \\
\hline \multirow{3}{*}{ Peak flow } & Magnitude & $\begin{array}{l}2,5 \text {, and } 10 \text {-year recurrence } \\
\text { interval peak flow }\end{array}$ & $\mathrm{X}$ & $\mathrm{X}$ & $\mathrm{X}$ \\
\hline & Duration & $\begin{array}{l}\text { cumulative \# of days } 2,5 \text {, and } \\
10 \text {-year peak flows are } \\
\text { exceeded in a year }\end{array}$ & $\mathrm{X}$ & $\mathrm{X}$ & \\
\hline & Frequency & $\begin{array}{l}\text { \# of times 2, 5, and 10-yr peak } \\
\text { flows are exceeded in a year }\end{array}$ & $\mathrm{X}$ & $\mathrm{X}$ & $\mathrm{X}$ \\
\hline \multirow{4}{*}{$\begin{array}{l}\text { Spring recession } \\
\text { flow }\end{array}$} & Magnitude & $\begin{array}{l}\text { flow at start of spring } \\
\text { recession }\end{array}$ & $\mathrm{X}$ & $\mathrm{X}$ & $\mathrm{X}$ \\
\hline & Timing & start date & $\mathrm{X}$ & $\mathrm{X}$ & $\mathrm{X}$ \\
\hline & Duration & \# days (start - end) & $\mathrm{X}$ & $\mathrm{X}$ & $\mathrm{X}$ \\
\hline & Rate of change & $\begin{array}{l}\text { percent decrease in flow per } \\
\text { day over spring duration }\end{array}$ & $\mathrm{X}$ & $\mathrm{X}$ & $\mathrm{X}$ \\
\hline \multirow{4}{*}{$\begin{array}{l}\text { Dry-season base } \\
\text { flow }\end{array}$} & Magnitude & $\begin{array}{l}\text { 50th, 90th percentile of daily } \\
\text { flow within dry-season }\end{array}$ & $\mathrm{X}$ & $\mathrm{X}$ & \\
\hline & Timing & start date & & $\mathrm{X}$ & \\
\hline & Duration & \# days (start - end) & $\mathrm{X}$ & $\mathrm{X}$ & \\
\hline & Rate of change & $\begin{array}{l}\text { cv of daily flow, flashiness } \\
\text { index }\end{array}$ & $\mathrm{X}$ & & \\
\hline
\end{tabular}


Table 2. Summary of functional flow components and characteristics that have been found through research and monitoring to link to aquatic species of management in the Goulburn River, Australia (Vietz et al., 2018; Webb et al., 2019). Flow metrics corresponding to each flow characteristic are specific to each river reach and determined based on reach-scale studies for environmental flow management.

\begin{tabular}{|c|c|c|c|}
\hline Flow Component & $\begin{array}{c}\text { Flow } \\
\text { Characteristic } \\
\end{array}$ & Flow Metric & Relation to Ecological Response \\
\hline \multirow{3}{*}{ Fall pulse flow } & Magnitude & $\begin{array}{l}\text { Peak relative to } \\
\text { channel capacity }\end{array}$ & $\begin{array}{l}\text { Sufficient volume to support riparian } \\
\text { vegetation recovery after summer }\end{array}$ \\
\hline & Duration & 1-2 weeks & $\begin{array}{l}\text { Sufficient, but not excessive, inundation } \\
\text { of riparian vegetation }\end{array}$ \\
\hline & Timing & Early autumn & $\begin{array}{l}\text { Before weather cools off in order to } \\
\text { allow a vegetative growth response }\end{array}$ \\
\hline \multirow{4}{*}{$\begin{array}{l}\text { Winter-spring } \\
\text { peak magnitude } \\
\text { (overbank) flows }\end{array}$} & Magnitude & $\begin{array}{l}\text { Peak greater than } \\
\text { channel capacity }\end{array}$ & $\begin{array}{l}\text { Sufficient volume to inundate the } \\
\text { floodplain and transport allochthonous } \\
\text { carbon into the river channel }\end{array}$ \\
\hline & Timing & Winter to late spring & $\begin{array}{l}\text { When water temperature is low enough } \\
\text { to limit excessive bacterial respiration }\end{array}$ \\
\hline & Duration & Less than 1 week & $\begin{array}{l}\text { Inundation of river bank features short } \\
\text { enough to limit bank erosion }\end{array}$ \\
\hline & Frequency & $\begin{array}{l}1 \text { in } 3 \text { years, or } 3-4 \\
\text { times over } 10 \text { years }\end{array}$ & $\begin{array}{l}\text { To support riparian and wetland habitat } \\
\text { persistence and channel secondary } \\
\text { production over time }\end{array}$ \\
\hline \multirow{3}{*}{ Spring pulse flow } & Magnitude & $\begin{array}{l}\text { Peak relative to } \\
\text { channel capacity }\end{array}$ & $\begin{array}{l}\text { Sufficient to cue native fish migration } \\
\text { and spawning }\end{array}$ \\
\hline & Timing & Late spring & $\begin{array}{l}\text { When water temperature is over } \\
\text { threshold for fish spawning }\end{array}$ \\
\hline & Duration & $1-3$ days & Sufficient to cue fish migration \\
\hline $\begin{array}{l}\text { Summer base } \\
\text { flow }\end{array}$ & Magnitude & $\begin{array}{l}\text { Volume relative to } \\
\text { channel capacity }\end{array}$ & $\begin{array}{l}\text { Sufficient to support in channel habitat } \\
\text { and connectivity for large-bodied native } \\
\text { fish }\end{array}$ \\
\hline
\end{tabular}




\section{Figure Legends}

Figure 1. Conceptual model for a functional flows approach to selecting flow metrics. Functional flow components are portions of the natural flow regime related to ecological, geomorphic, or biogeochemical processes that are quantified by flow characteristics, which in turn are measured by discrete numeric flow metrics.

Figure 2. Functional flow components (boxes) for a mixed rain-snowmelt runoff system (hydrograph) typical to rivers in California, with key flow characteristics for each flow component (table). Other seasonal river systems, such as those in Australia, have similar functional flow components defined by intra-annual high and low flows. 


\section{Functional Flow Components}

e.g. Peak Flows, Spring Recession,

Dry Season Low Flows

\section{Flow Characteristics}

e.g. Magnitude, Timing, Duration,

Frequency, Rate of Change

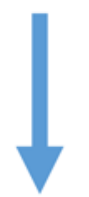

\section{Flow Metrics}

e.g. $5 \%$ exceedance flow, Percent decrease per day, Richards-Baker Flashiness Index 


\section{Functional Flow Components}

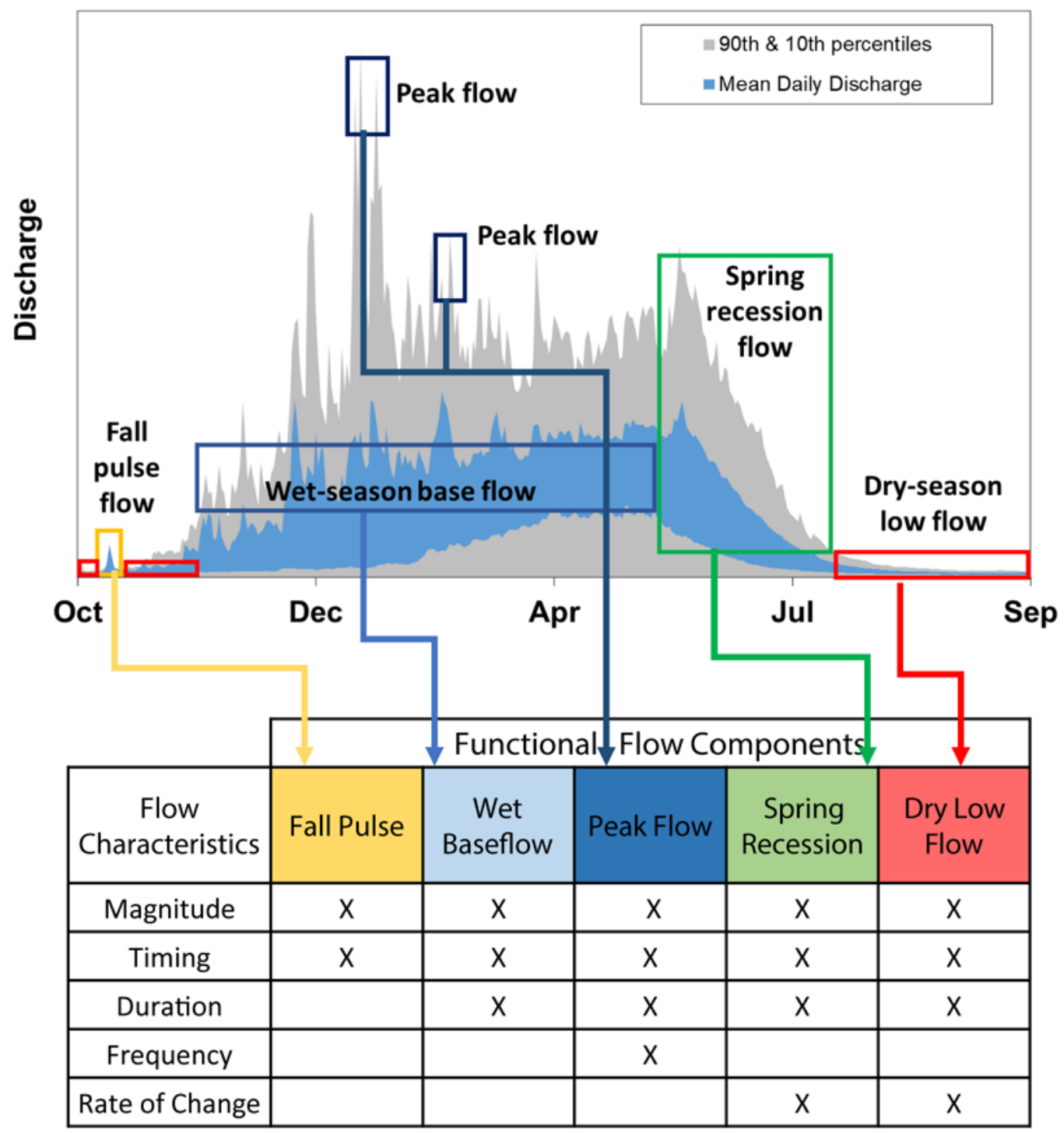

This article is protected by copyright. All rights reserved. 


\section{Functional Flow Components}

e.g. Peak Flows, Spring Recession,

Dry Season Low Flows

Flow Characteristics

e.g. Magnitude, Timing, Duration,

Frequency, Rate of Change

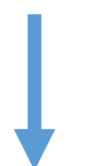

Flow Metrics

e.g. $5 \%$ exceedance flow, Percent decrease per day, Richards-Baker

Flashiness Index

RRA_3575_FF_Figures_Final Fig 1.tif 


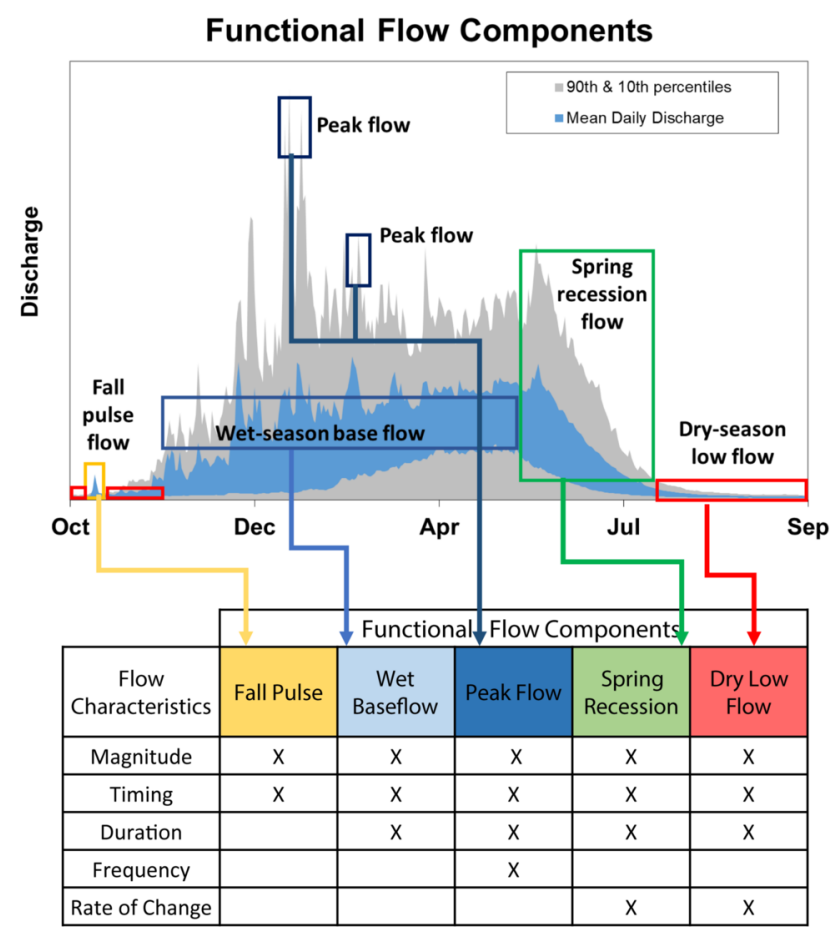

RRA_3575_FF_Figures_Final Fig 2.tif

This article is protected by copyright. All rights reserved. 


\section{University Library}

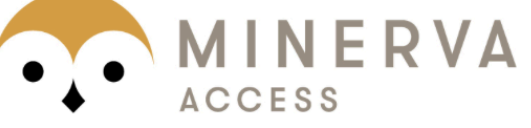

A gateway to Melbourne's research publications

Minerva Access is the Institutional Repository of The University of Melbourne

Author/s:

Yarnell, SM;Stein, ED;Webb, JA;Grantham, T;Lusardi, RA;Zimmerman, J;Peek, RA;Lane, BA;Howard, J;Sandoval-Solis, S

Title:

A functional flows approach to selecting ecologically relevant flow metrics for environmental flow applications

Date:

2020-02-03

Citation:

Yarnell, S. M., Stein, E. D., Webb, J. A., Grantham, T., Lusardi, R. A., Zimmerman, J., Peek, R. A., Lane, B. A., Howard, J. \& Sandoval-Solis, S. (2020). A functional flows approach to selecting ecologically relevant flow metrics for environmental flow applications. RIVER RESEARCH AND APPLICATIONS, 36 (2), pp.318-324. https://doi.org/10.1002/rra.3575.

Persistent Link:

http://hdl.handle.net/11343/275246 